Agro-Science Journal of Tropical Agriculture, Food, Environment and Extension Volume 11 Number 3 September 2012 pp $20-26$

TSSN TII9-7455

\title{
NUTRIENT ELEMENTS DISTRIBUTION IN CULTIVATED AND UNCULTIVATED SOILS AND SEDIMENTS OF SURROUNDING STREAMS OF OKAI AND KWANTA IN ABIRIBA, ABIA STATE, SOUTHEASTERN NIGERIA
}

\author{
Jidere, C.M., Ene, J., Inem, U. S. and Uzoh, I.M. \\ Department of Soil Science University of Nigeria, Nsukka, Nigeria. \\ *Corresponding author :jiderecm@yahoo.com
}

\begin{abstract}
A study was conducted in 2009 to investigate the distribution of nutrient elements in cultivated and uncultivated soils, and sediments of surrounding Okai and Kwanta streams in Abiriba, Abia State of Southeastern Nigeria with the intention to determine the impact of agricultural practices on the water quality of these streams. The Okai stream was surrounded by a three-year old fallow land dominated by oil palm (Elaeis guineensis), raphia palm (Raphia spp), cocoyam (Colocasia esculentus), avocado tree (Persea Americana), shrubs (mainly Sponelias munibin) and sparsely distributed grasses. The upland farm close to this stream was grown to cassava (Manihot esculenta), pepper (Capsicum spp), and yam (Dioscorea spp). The Kwanta stream was located near a six-year old fallow land with a scanty bush predominantly composed of bamboo tree (Bambusa spp), oil palm (Elaeis guineensis), shrubs and grasses. The upland around this stream was a cultivated cassava farm. Crop rotation was the only means of replenishing used nutrients. Three sediment samples were collected at random at three points within the edges of each stream, bringing the total number of sediment sample to six. Three soil samples were collected randomly at two depths (0-20cm and 20$40 \mathrm{~cm}$ ) within the cultivated as well as the uncultivated farm, giving a total of 24 soil samples. Physical (particle size distribution) and selected chemical laboratory analyses were carried out on the soil and sediment samples. As the results showed, though both soils were generally low in nutrient elements, the Kwanta soil was a little more fertile than that of Okai. The cultivated soils were richer chemically than the uncultivated soils at both Okai and Kwanta sites. The nutrient load of Kwanta stream was higher than that of Okai stream, and this translated into more eutrophication in the former than in the latter. The sediments from the two streams were sandy, while the cultivated and uncultivated soils from the two study locations were loamy sand in texture. The soils from the sites varied $(P<0.05)$ significantly in $\mathrm{Na}$ and CEC values, while the sediments from the two streams showed significant difference $(P<0.05)$ in $K$ and $H$ contents. The soils of Okai and Kwanta farms are similar to the sediments of their respective streams in terms of chemical properties; this implies that the agricultural activities in the study area exerted some influence on the sediment and water quality of nearby streams.
\end{abstract}

\section{INTRODUCTION}

Water is vital to the existence of all living organisms, but this valued resource is increasingly being polluted and degraded as human populations grow and demand more water of high quality for domestic and economic purposes. Water abstraction for domestic use, agricultural production, mining, industrial production, power generation, and forestry practices can lead to deterioration in water quality and quantity that impact not only the aquatic ecosystem, but also the availability of safe water for human consumption (Carr and Neary, 2006). Human activity in the form of agricultural production exerts a great deal of influence on the concentration, distribution, and availability of physical, chemical and biological substances between the terrestrial and aquatic environments. The extent to which agriculture contributes to variations in the composition and distribution of nutrient elements in neighbouring water bodies is governed by the intrinsic soil properties, soil management practices, climate, and topographic characteristics of the area under consideration. The physical, chemical and biological composition of a water body is determined, to a large extent, by myriads of human activities such as agricultural, recreational, and industrial activities, and to a lesser extent, by natural 
influences such as the weathering of bedrock minerals, the atmospheric processes of evapotranspiration and the deposition of dust and salt by wind, the natural leaching of organic matter and nutrients from soil, the hydrological factors that result in runoff, and the biological processes within the aquatic environment that can alter the physical and chemical composition of water. The degradation of physical and chemical water quality due to human influences is often gradual, and subtle adaptations of aquatic ecosystems to these changes may not always be readily detected until a dramatic shift in ecosystem condition occurs (Sheffer et al., 2001).

Studies on chemical characterization of soils in relation to changes in the chemical enrichment of a body of water began several years ago, particularly in the developed world. In the developing world, however, lack of detailed information on the soil resources and their response to management has been one of the major factors limiting the conservation of soil and water resources. Much of the information lacking about the soil is particularly true of soils formed in alluvial and stream sediment (Okusami et al., 1987).

Sediment in our rivers is an important habitat as well as a main nutrient source for aquatic organisms. Furthermore, sediments have an impact on ecological quality because of their quality, or their quantity, or both (Stronkhorst et al., 2004). The in-stream sediments play a critical role in transport of nutrient elements between the landscape and downstream water bodies and, therefore, the role of in-stream processes must be considered to assess the ultimate impact of agricultural lands on receiving waters (Karthikeyan, 2008). The sediments, both suspended and precipitated substances stored on the water bottom, form a reservoir for many pollutants and trace substances of low solubility and low degree of degradability (Biney et al., 1994). Sediment transport into aquatic ecosystems results from almost all human land use and industrial activities, including agriculture, forestry, urbanization, mining, and some industrial activities. Increases in sediment transport to aquatic ecosystems are typically observed as bankside vegetation is degraded or removed, rivers are channelized to enable development closer to streambanks, and natural land cover is removed or replaced by human-built land cover (Carr and Neary, 2006). Many toxic organic contaminants, such as pesticides or their breakdown products, are strongly associated with silt, clay and organic carbon transported by rivers; thus sediments act as an agent in the process of eutrophication and toxicity in aquatic organisms (Ongley, 1996; Owens et al., 2005).

The major nutrient elements involved in the metabolism and growth of organisms include carbon, hydrogen, oxygen, nitrogen, phosphorous, potassium, sulphur, magnesium, and calcium. Out of these elements, nitrogen and phosphorous have been shown to be the two principal nutrients that most commonly regulate the biomass of algae and aquatic plant (Carr and Neary, 2006). An understanding of the soil, climatic and physiographic characteristic of an area close to a water body is required to assess the environmental, ecological, and health impact of science-based, fertility-modifying inputs like $\mathrm{N}$, and P-rich fertilizers on surface and ground waters.

Because the soil is located at the interface where the atmosphere and land meet, the soil acts like a policeman directing traffic by determining the amount of nutrient elements that are in the soil, that enters the soil and leaves the soil (Davidson, 2008). The soil functions not only within managed agricultural ecosystem in providing a medium for the production of food and fibre, but also functions within natural ecosystem boundaries in regulating environmental quality and in the preservation of biodiversity. A periodic evaluation of the chemical composition of cultivated and undisturbed soils and sediments of streams surrounding farmlands will provide information on the dynamic distribution of nutrients in soils and sediments as a function of agricultural activity. The presence of available plant nutrients may determine if a soil is suitable for plants or if a stream is polluted (Rim-Rukeh, 2006).

Kwanta and Okai streams are the most valuable sources of drinking water in Abiriba community, southeastern Nigeria. These natural water reserves need to be conserved and managed sustainably. There has not been any detailed study of the soils and rivers of Abiriba in the past, hence, it is difficult to predict the influence of agricultural activities on the streams. Again, in order to ensure a sustainable management of the soil and water resources of this area, information on the soil chemical characteristics is indispensable.

The objective of this work was, therefore, to investigate the nutrient elements distribution in cultivated and uncultivated soils and sediments from the surrounding Okai and Kwanta streams in Abiriba, Abia State of Southeastern Nigeria with a view to assessing the impact of agricultural activities on the quality of the streams.

\section{MATERIALS AND METHODS Site Description}

The study was carried out at the ancient kingdom of Abiriba, a rural-urban community, which lies between latitude $5^{0} \mathrm{~N}$ and longitude $7^{0} \mathrm{E}$. It is a town within the Southeastern Nigeria. The city is on the North-East of Umuahia, the Abia State capital, and is located at a distance of about $54 \mathrm{~km}$ from the State capital, and about $28 \mathrm{~km}$ from Bende Local Government in the South, about $48 \mathrm{~km}$ from Arochukwu town in the East and about $32 \mathrm{~km}$ from Afikpo town in the North (Mbiriba, 1989).

The area is characterized by a humid tropical climate with wet (April-October) and dry (November-March) 
seasons and a mean annual rainfall of approximately $1600.8 \mathrm{~mm}$. The mean annual temperature stands at about $34.10^{\circ} \mathrm{C}$ during the day and about $21.31^{\circ} \mathrm{C}$ during the night. The area has a rainforest vegetation, with progressive transition to the Guinea savannah agro-ecological zone, following human activities.

The fallow land around the Okai stream was a three year old bush dominated by oil palm (Elaeis guineensis), raphia palm (Raphia spp), cocoyam (Colocasia esculentus), avocado tree (Persea Americana) and some shrubs (notably Sponelias munibin) and scanty grasses. The upland farm near this stream was grown to cassava (Manihot esculenta), pepper (Capsicum spp) and yam (Dioscorea spp). The stream is fresh during rainy seasons and has debris and foams during dry seasons. The upper course where wild trees grow has shallow basins on a gentle to moderate slope.

The Kwanta stream was surrounded by a six-year old fallow land composed of a scanty bush, predominated by bamboo tree (Bambusa spp), oil palm (Elaeis guineeniis), shrubs and grasses. Another upland close to this stream was a cultivated cassava farm. Lizard, snake, and tortoise are the popular reptiles found within the area. Crop rotation and intercropping are the major traditional farming practices within the study area.

\section{Field Work}

Sediment samples were collected in January, 2009 at random at three points each from Kwanta and Okai streams, bringing the total number of sediment sample to six. Three soil samples were collected randomly at two depths $(0-20 \mathrm{~cm}$ and $20-40 \mathrm{~cm})$ within the cultivated as well as the uncultivated farm, giving a total of 24 soil samples.

\section{Laboratory Work}

All the samples collected were air-dried and subsequently passed through a $2 \mathrm{~mm}$ sieve. This size fraction of soil and sediment samples were used for physical and chemical analysis.

\section{Physical Analysis}

Particle size distribution was determined by the hydrometer method as described by Gee and Or (2002). The result was reported as percentage sand, silt and clay using the USDA textural triangle.

\section{Chemical Analysis}

The $\mathrm{pH}$ of the soil was determined in duplicate, both in distilled water and in $0.1 \mathrm{~N} \mathrm{KCl}$ solution, using a soil/water ratio of 1:2.5. After stirring for 30 minutes, the $\mathrm{pH}$ values were read off using a Beckman zeromatic $\mathrm{pH}$ meter (Peech, 1965). Total nitrogen was determined using the micro-Kjeldhal distillation method of Bremner (1996). Organic carbon was determined using the method described by Nelson and Sommers (1982); the percentage organic matter was calculated by multiplying the value for organic carbon by the "Van Bemmeler Factor" of 1.724. Exchangeable acidity was measured using the titrimetric method of McLean (1982). Exchangeable bases $\left(\mathrm{Na}^{+}\right.$and $\left.\mathrm{K}^{+}\right)$were extracted with IN ammonium acetate solution $\left(\mathrm{NH}_{4} \mathrm{OAC}\right)$, and determined using flame photometer, while $\mathrm{Ca}^{2+}$ and $\mathrm{Mg}^{2+}$ were determined by the complexometric titration method (Jackson, 1958). Available phosphorus was determined by the Bray-2 method as described by Page et al. (1982). The cation exchange capacity of the samples were determined by ammonium acetate ( $\left.\mathrm{NH}_{4} \mathrm{OAC}\right)$ displacement (Jackson, 1958), while the effective cation exchange capacity (ECEC) was evaluated by the summation method as follows:

$\mathrm{ECEC}=\mathrm{TEB}+\mathrm{TEA}$

Where;

$\mathrm{ECEC}=$ Effective cation exchange capacity $(\mathrm{cmolkg}$ ${ }^{1}$ soil)

TEB $=$ Total exchangeable bases $\left(\mathrm{cmolkg}^{-1}\right.$ soil $)$ TEA $=$ Total exchangeable acidity $\left(\mathrm{cmolkg}^{-1}\right.$ soil $)$.

Base saturation (BS) was calculated by dividing total exchangeable bases (TEB) by cation exchange capacity value and multiplying by 100 . This is expressed thus:

$\% \mathrm{BS}=\frac{T E B}{C E C} \times \frac{100}{1}$

\section{Data Analysis}

The data generated from the study were subjected to the analysis of variance (ANOVA) statistics using Genstat Discovery Edition 3, while significant differences in treatment means were determined using Fisher's Least Significance Method (LSD) at $5 \%$ probability level.

\section{RESULTS AND DISCUSSION}

Physical property (particle size distribution) of soils and sediments of Okai and Kwanta Study Locations

The particle size distribution of the soils and sediments of Okai and Kwanta study locations is shown in tables 1 and 2 . With the exception of the soil from the fallow land of Kwanta, all the soils from the fallow and cultivated farms were loamy sand in texture, in contrast to the sediments from the surrounding streams which were sandy. As would be expected, the sandy nature of the stream-based sediments could be attributed to the preferential translocation of sand sized particles from the upland soils down to the streams. 
Table 1: Particle size distribution of the soils of Okai and Kwanta study sites

\begin{tabular}{|c|c|c|c|c|c|}
\hline Location & Soil Depth (cm) & \% Clay & \% Silt & \% Sand & Textural Class \\
\hline \multirow[t]{2}{*}{ Okai farmland } & $0-20$ & 11.87 & 4.61 & 83.52 & \multirow{2}{*}{$\begin{array}{c}\text { Loamy sand } \\
\text { ” }\end{array}$} \\
\hline & $20-40$ & $11-20$ & 3.95 & 84.85 & \\
\hline \multirow[t]{2}{*}{ Okai fallow land } & $0-20$ & 12.53 & 5.28 & 82.19 & $"$ \\
\hline & $20-40$ & 11.20 & 7.28 & 81.52 & $"$ \\
\hline \multirow[t]{2}{*}{ Kwanta farmland } & $0-20$ & 11.80 & 12.61 & 75.62 & $"$ \\
\hline & $20-40$ & 12.50 & 10.61 & 79.85 & 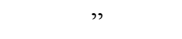 \\
\hline \multirow[t]{2}{*}{ Kwanta fallow land } & $0-20$ & 7.20 & 4.61 & 88.19 & \multirow{2}{*}{ Sandy soil } \\
\hline & $20-40$ & 7.20 & 5.95 & 86.85 & \\
\hline Mean & & 10.69 & 6.86 & 82.82 & \\
\hline $\mathrm{CV} \%$ & & 19.18 & 42.88 & 16.97 & \\
\hline
\end{tabular}

Table 2: Particle size distribution of the sediments of Okai and Kwanta streams

\begin{tabular}{lllll}
\hline Location & \% Clay & \% Silt & \% Sand & Textural Class \\
\hline Okai & 7.9 & 4.0 & 88.2 & Sandy soil \\
Kwanta & 7.2 & 3.3 & 89.5 & Sandy soil \\
\hline Mean & 7.55 & 3.65 & 88.85 & \\
CV\% & 3.18 & 9.59 & 0.89 & \\
\hline CV = Coefficient of variation
\end{tabular}

$\mathrm{CV}=$ Coefficient of variation

Chemical Properties of the Cultivated and Fallow Soils of Okai and Kwanta Study Sites

The chemical properties of the soils of Okai and Kwanta study areas are presented in table 3. From the $\mathrm{pH}$ values (both in $\mathrm{H}_{2} \mathrm{O}$ and in $0.1 \mathrm{~N} \mathrm{KCl}$ ) which ranged from 2.9-4.1, the soils could be said to be acidic in reaction. This could be related to high rate of leaching of exchangeable cations out of the root zone following high rainfall events characteristic of tropical climate. There was no significant difference in $\mathrm{pH}$ between the cultivated and the uncultivated plots at Okai and Kwanta sites. However, the cultivated soils were slightly more acidic than the fallow soils, probably as a result of accelerated leaching following tillage. Aluminum ( $\mathrm{Al}$ ) was found to be in trace amounts at the sites - an indication of absence of Al toxicity in the soils. Apart from Calcium (Ca), which was in relatively high concentration $(15.7-17.23 \mathrm{cmol} / \mathrm{Kg}$ soil), the other exchangeable cations (sodium $(\mathrm{Na})$, potassium $(\mathrm{K})$, and Magnesium $(\mathrm{Mg})$ ) were low. The observed high level of $\mathrm{Ca}$ relative to other cations may have resulted from the chemical composition of the parent material from which the soils were formed. Soils that originate from shale contain high $\mathrm{Ca}$, since shale contains coarse sandstones with thin shelly limestone material. Among the exchangeable cations, $\mathrm{Na}$ showed significant $(P<0.05)$ variation between the tilled and untilled Okai and Kwanta soils. Generally, the soils from the two sites were characterized by low levels of organic matter (OM), total nitrogen (TN), cation exchange capacity (CEC), available phosphorous (Av. P), and hydrogen (H). The observed trend in the nutrient status of the study area may be a combined effect of parent material, climate, and land use history. The low organic matter content of the soils may be due to increased decomposition and mineralization of organic materials under high temperature regime in the tropics, and continuous cultivation without adequate application of organic amendments. A significant difference $(\mathrm{P}<0.05)$ occurred in the level of CEC between the cultivated and fallow soils of Okai and Kwanta areas. The low values of CEC may be due to the low contents of organic matter and exchangeable $\mathrm{Mg}, \mathrm{Ca}, \mathrm{Na}$, and $\mathrm{K}$, and the leaching process undergone by the soils. The low TN and Av.P may be attributed to the low organic forms of nitrogen and phosphorus resulting from the low organic matter content of the soils. Again,the observed low TN could have resulted from leaching occasioned by high intensity rains, while it may be possible that the low $\mathrm{pH}$ of the soils could be contributory to the reduced solubility and availability of phosphorus resulting from P-fixation in acid soils. The cultivated plots had slightly higher nutrient values than the fallow plots at Okai and Kwanta. It could be inferred that cultivation increases the risk of streams being contaminated by nutrient elements within the study area. Kwanta fallow and farm had $10 \%$ and 5\% more nutrients than Okai fallow and farm, respectively. The greater variation observed in the nutrient status between the fallow plots could be related to the disproportionate 6 and 3 years of fallow periods at Kwanta and Okai sites, respectively. The chemical fertility status of Kwanta soil surpasses that of Okai by $7.8 \%$. Specifically, the amounts of $\mathrm{N}$ and $\mathrm{P}$ were higher in Kwanta soil than in Okai soil; consequently, the stream receiving water from Kwanta plot should be expected to be more prone to eutrophication and pollution than the stream receiving water from Okai plot. 
Table 3: Chemical properties of the soils of Okai and Kwanta study locations

\begin{tabular}{|c|c|c|c|c|c|c|c|c|c|c|c|c|c|c|}
\hline Location & $\mathrm{pH}_{\mathrm{H20}}$ & $\mathbf{p H}_{\mathrm{kcl}}$ & $\operatorname{OM}(\%)$ & $\mathbf{N}(\%)$ & $\mathbf{N a}$ & $\mathbf{C a}$ & $\begin{array}{l}\mathrm{K} \\
\mathrm{mol} / \mathrm{kg}\end{array}$ & Mg & Bs (\%) & \multicolumn{2}{|c|}{$\begin{array}{c}(\mathrm{cmol} / \\
\mathrm{kg})\end{array}$} & $\begin{array}{l}\mathrm{P} \\
\mathrm{mg} / \mathrm{kg}\end{array}$ & \multicolumn{2}{|c|}{$\begin{array}{c}(\mathrm{cmol} / \\
\mathrm{kg})\end{array}$} \\
\hline $\begin{array}{l}\text { Okai } \\
\text { fallow } \\
\text { land }\end{array}$ & 4.1 & 3.2 & 1.11 & 0.05 & 0.12 & 15.7 & 0.13 & 0.87 & 28.0 & 18.57 & 6.27 & 11.8 & 1.73 & Trace \\
\hline $\begin{array}{l}\text { Kwanta f } \\
\text { allow } \\
\text { land }\end{array}$ & 3.9 & 3.1 & 1.23 & 0.05 & 0.13 & 15.87 & 0.19 & 1.17 & 33.6 & 19.28 & 7.07 & 12.3 & 1.93 & Trace \\
\hline $\begin{array}{l}\text { Okai } \\
\text { farmland }\end{array}$ & 3.9 & 3.0 & 0.80 & 0.04 & 0.09 & 16.50 & 0.18 & 0.90 & 35.1 & 19.48 & 5.07 & 10.6 & 1.80 & Trace \\
\hline $\begin{array}{l}\text { Kwanta } \\
\text { farmland }\end{array}$ & 3.9 & 2.9 & 1.13 & 0.07 & 0.12 & 17.23 & 0.21 & 1.33 & 32.0 & 20.77 & 9.53 & 11.5 & 1.87 & Trace \\
\hline $\begin{array}{l}\text { F-LSD } \\
(\mathrm{P}<0.05)\end{array}$ & N.S & N.S & NS & NS & 0.08 & NS & NS & NS & NS & NS & 0.21 & NS & NS & Trace \\
\hline $\mathrm{CV} \%$ & $8.0 \%$ & 4.3 & 43.1 & 30.1 & 19.9 & 7.2 & 42.6 & 41 & 24 & 7.7 & 21.1 & 12.2 & 20.4 & Trace \\
\hline
\end{tabular}

Table 4: Chemical properties of the sediments of Okai and Kwanta streams

\begin{tabular}{|c|c|c|c|c|c|c|c|c|c|c|c|c|c|c|}
\hline Locations & $\begin{array}{l}\mathrm{pH}_{\mathrm{H}} \\
20\end{array}$ & $\mathbf{p H}_{\mathrm{kcl}}$ & $\begin{array}{l}\text { OM } \\
\%\end{array}$ & $\begin{array}{l}\mathbf{N} \\
\%\end{array}$ & \multicolumn{4}{|c|}{$(\mathrm{cmol} / \mathrm{kg})$} & $\begin{array}{c}\text { BS } \\
\%\end{array}$ & \multicolumn{2}{|c|}{$\begin{array}{c}(\mathbf{c m o l} \\
/ \mathbf{k g}) \\
\end{array}$} & $\begin{array}{l}\text { P } \\
\mathrm{Mg} \\
/ \mathrm{kg} \\
\end{array}$ & \multicolumn{2}{|c|}{$\begin{array}{c}(\mathrm{cmol} \\
/ \mathrm{kg})\end{array}$} \\
\hline $\begin{array}{l}\text { Okai } \\
\text { sediment }\end{array}$ & 4.43 & 4.03 & 0.41 & 0.02 & 0.14 & 16.60 & 0.07 & 0.73 & 48.7 & 19.14 & 2.53 & 12.4 & 1.60 & Trace \\
\hline $\begin{array}{l}\text { Kwanta } \\
\text { sediment }\end{array}$ & 4.10 & 3.36 & 0.34 & 0.02 & 0.14 & 15.27 & 0.12 & 1.01 & 58.0 & 18.60 & 2.53 & 12.4 & 2.00 & Trace \\
\hline $\mathrm{t}(\mathrm{P}<0.05))$ & N.S & 0.68 & NS & NS & NS & NS & 0.02 & NS & NS & NS & NS & NS & 0.23 & Trace \\
\hline CV\% & 7.0 & 2.9 & 32.4 & 43.0 & 15.2 & 9.7 & 38.7 & 32 & 29.1 & 9.5 & 17.2 & 6.4 & 14.8 & Trace \\
\hline
\end{tabular}

OC = Organic carbon; OM = Organic matter; N = Nitrogen; Na = Sodium; Ca = Calcium; $\mathbf{K}=$ Potassium; Mg = Magnesium;

$\mathrm{BS}=$ Base saturation; $\mathrm{ECEC}=$ Effective cation exchange capacity $\mathbf{C E C}=$ Cation exchange capacity; $\mathbf{P}=\mathbf{P h o s p h o r u s} ; \mathrm{H}=$

Hydrogen; $\mathrm{Al}=$ Aluminiun; $\mathrm{t}(\mathrm{P}<\mathbf{0 . 0 5}))=$ Least significant difference at $5 \%$ probability level; $\mathrm{CV}=\mathrm{Coefficient}$ of variation; $\mathrm{NS}$

= Non significant.

\section{Chemical Properties of the Sediments of Okai and}

\section{Kwanta Streams}

The results of the nutrient distribution of sediments derived from Okai and Kwanta streams are presented in table 4. Based on the mean values of all the chemical parameters tested, with the exclusion of $\mathrm{pH}$ (in $\mathrm{H}_{2} \mathrm{O}$ and in $0.1 \mathrm{~N} \mathrm{KCl}$ ), the nutrient load of Kwanta stream was greater than that of Okai stream by $7.8 \%$, the exact percentage by which Kwanta upland soil was richer in nutrients than the Okai upland soil. The chemical composition of Okai and Kwanta streams were statistically the same with respect to the chemical parameters determined, except for $\mathrm{pH}$ in $0.1 \mathrm{~N} \mathrm{KCl}, \mathrm{K}$ and $\mathrm{H}$, which showed significant variation $(\mathrm{P}<0.05)$ between the two streams. The $\mathrm{pH}$ (in $0.1 \mathrm{~N} \mathrm{KCl}$ ) of Kwanta stream was $19.9 \%$ less than that of Okai stream. $\mathrm{P}$ and $\mathrm{H}$ were $71 \%$ and $25 \%$ higher in Kwanta stream than in Okai stream, respectively. The acidity of the sediments from the streams could be accounted for by the high demand for $\mathrm{Ca}, \mathrm{Mg}$, and $\mathrm{Na}$ by aquatic organisms for their biological activities (Herbert, 2008). The organic matter contents of the sediments were low. This may be linked to the fact that the sediments were predominantly sand which is deficient in organic matter. The low organic matter content gave rise to the observed low $\mathrm{N}$ concentration $(0.02 \%)$. The exchangeable cations were generally low, except for $\mathrm{Ca}$ (16.60 and 15.27 $\mathrm{cmol} / \mathrm{Kg}$ soil for Okai and Kwanta streams, respectively) which was high compared to other cations. Kwanta stream had a significantly higher $\mathrm{K}$ value $(0.12 \mathrm{cmol} / \mathrm{Kg}$ soil $)$, in relation to Okai stream with a $\mathrm{K}$ value of $0.07 \mathrm{cmol} / \mathrm{Kg}$ soil. The variation in the distribution of nutrient elements between the two streams may be related to differences in the intensity of agricultural activities and management practices around the streams. 


\section{Chemical Properties of the Soils and Sediments of Okai and Kwanta Study Sites}

The soils from the upland farms were slightly more acidic than the sediments from the neighbouring streams at Okai and Kwanta study locations (tables 3 and 4). From the mean values of the chemical parameters evaluated, OM, N, Ca, K, $\mathrm{Mg}, \mathrm{ECEC}, \mathrm{CEC}$ and $\mathrm{H}$ were found in higher concentrations in the upland soils, whereas $\mathrm{Na}$, BS (base saturation) and $\mathrm{P}$ were in higher levels in the stream-based sediments. The differences in nutrient concentrations between the soils and sediments were not significant statistically. This implies that significant proportion of the nutrients in Okai and Kwanta streams originated from the surrounding upland soils. In other words, the agricultural activities in nearby upland farms affected significantly the quality and chemical composition of Okai and Kwanta streams.

\section{CONCLUSION}

The sediments from Okai and Kwanta streams were predominantly sand while the surrounding upland soils were loamy sand. Al was in trace quantities in the soils and sediments of the study area. Kwanta soil was better than Okai soil in nutrient composition by $7.8 \%$; Kwanta stream was higher in nutrient enrichment than Okai stream by $7.8 \%$. The cultivated soils were slightly richer in nutrients than the fallow soils at both Okai and Kwanta sites. $\mathrm{Na}$ and $\mathrm{CEC}$ varied significantly ( $\mathrm{P}$ $<0.05$ ) between the cultivated and fallow soils of Okai and Kwanta study areas. Significant variation $(\mathrm{P}<0.05)$ occurred in $\mathrm{pH}(0.1 \mathrm{~N} \mathrm{KCl}), \mathrm{K}$, and $\mathrm{H}$ between Okai and Kwanta streams. The majority of the nutrient elements evaluated were in higher concentrations in the soils than in the sediments, though the differences in concentrations were not significant. The similarity in the nutrient elements distribution between the soils and the surrounding streams at Okai and Kwanta sites, in Abiriba, Abia State of Southeastern Nigeria shows that the agricultural activities within these areas actually influenced considerably the nutrient distribution, and by extension, the quality and productivity of the streams. The chemical composition of the streams was influenced more by the soil under cultivation than by the soil under fallow.

\section{REFERENCES}

Biney, C., Amazu, A.T., Calamari, D., Kaba, N., Mbome, I.L., Naeve, H., Ochumba, P.B.O., Osibanjo, O., Radegonde, V., and Saad, M.A.H. (1994), Review of heavy metals in the African Aquatic Environment, Ecotoxicology and Environmental Safety, 31, 134-159.

Bremner, J.M. (1996), Nitrogen-total. In: Sparks, D.L. (ed), Methods of Soil Analysis, Part 3, Chemical Methods. American Soc. Agron. 5: 1085-1121.

Carr, G.M. and Neary, J.P. (2006), Water Quality for Ecosystem and Human Health. United Nations Environment Programme Global Environment Monitoring System (GEMS)/ Water Programme, Ontario (available at: http://www.gemswater.org/).

Gee, G.W. and Or, D. (2002), Particle Size Analysis. In: Dane, J.H. and Topp, G.C. (eds). Methods of Soil Analysis. Part 4, Physical Methods. Soil Sci. Soc. Am. 5: 255-293.

Jackson, M.I. (1958), The Soil Chemical Analysis, London: Constable.

Mclean, E.O. (1982), Soil $\mathrm{pH}$ and lime requirements. In: Page, A.L. (eds) methods of Soil Analysis, Part 2. Chemical and Microbial Properties. Second edition Agronomy Series No. 9, Madison, WI, USA, ASA, SSSA.

Nelson, D.W. and Summers, L.E. (1982), Total carbon, organic carbon, and organic matter. In: Page, A.L. (Ed). Methods of Soil Analysis. Part 2. Chemical and Microbiological Properties, Second ed. Agronomy. Series No. 9, Madison, WI, USA, ASA, SSSA.

Ongley, E.D. (1996), Control of water pollution from agriculture: FAO irrigation and drainage paper 55. Food and Agriculture Organization of the United Nations: Rome. 
Owens, P.N., Batalla, R.J., Collins, A.J., Gomez, B., Hicks, D.M., Horowitz, A.J., Kondolf, G.M., Marden, M., Page, M.J., Peacock, D.H., Petticrew, E.L., Salomons, W., and Trustrum, N.A. (2005), "Fine-grained sediment in river systems; environmental significance and management issues". River Research and Applications 21: 693717.

Page, A.L., Miller, R.A. and Keeney, D.R. (eds) (1982), Methods of Soil Analysis, Part 2. American Soc. Agron. Madison 579pp.

Peech, M. (1965), Hydrogen ion activity. In: Black, C.A. (ed). Methods of Soil Analysis. Part 2. Am. Soc. Agron. 9: 914926.
Rim-Rukeh (2005), Effects of Agricultural Activities on the Water Quality of Orogodo River. Journal of Applied Sciences Research 295, 256-259.

Scheffer, M.S., Carpenter, J.A. Foley, C. Folke, B., Walker (2001), "Catastrophic Shifts in Ecosystem”, Nature 413: 591-596.

Stronkhorst, J., Brills, J., Batty, J., Coquery, M., Gardner, M., Mannio, J., O’Donnel C., Steenwijk, J. and Frintrop, P. (2004), Discussion Document on Sediment Monitoring Guidance for the EU Water Framework Directive. Version 2. EU Water Framework Directive Expert Group on Analysis and Monitoring of Priority Substances. May 25 ${ }^{\text {th }}, 2004$. 